九州大学学術情報リポジトリ

Kyushu University Institutional Repository

\title{
消化管粘膜下病変に対する人工知能を併用した超音 波内視鏡診断の有用性
}

圜田，洋介

http://hdl. handle. net/2324/4474982

出版情報：Kyushu University，2020，博士（医学），課程博士 バージョン:

権利関係: Public access to the fulltext file is restricted for unavoidable reason (2) 
氏 名: 蔉田 洋介

論文名: Efficacy of endoscopic ultrasound with artificial intelligence

for the diagnosis of gastrointestinal stromal tumors

（消化管粘膜下病変に対する人工知能を併用した超音波内視鏡診断の有用性）

区 分：甲

\section{論文内容の要旨}

超音波内視鏡（endoscopic ultrasound：EUS）は粘膜下病変（subepithelial lesion：SEL） を評価するのに適した機器であると報告されているが、EUS 画像だけでは病変が gastrointestinal stromal tumor（GIST）かnon-GIST であるかを鑑別することは難しい。 本研究では SEL の EUS 画像に対する人工知能（artificial intelligence：AI）を用いた診 断システムを構築し、その有用性を評価した。 $20 \mathrm{~mm}$ 以上ならびに $20 \mathrm{~mm}$ 未満の胃 SEL に対す る EUS 画像 30 枚ずつを、AI を用いた診断システム（EUS-AI）と EUS 熟練医 3 名がそれぞれ 診断し最終病理診断に対寸る診断精度を評価比較した。なお EUS-AI は EUS 画像 1 枚のみを 用いて診断し、EUS 熟練医は全画像を評価した。ROC 曲線分析では EUS-AI の感度および特 異度は、SEL サイズにかかわらずEUS 熟練医よりも常に高かった。またガイドラインで精査 を要するとされる $20 \mathrm{~mm}$ 以上の SEL に対する EUS-AI の ROC 曲線の曲線下面積 は EUS 熟練医 の 0.684 に対し EUS-AI は 0.965 で、EUS-AI が統計学的に有意に高かった。人工知能を併用 した超音波内視鏡画像診断は、胃 SEL 診断のための良い選択肢となりえるものと考えられ た。 